\title{
Canadian Association
}

\section{fOR Refugee and ForCed Migration STUDIES (CARFMS) CONFERENCE, 2012}

\author{
RESTRUCTURING REFUGE AND \\ Settlement: Responding to THE \\ Global Dynamics of Displacement
}

\author{
VOLKER TÜRK
}

This was the keynote address at the 2012 Conference organized by the Canadian Association for Refugee and Forced Migration Studies (CARFMS), hosted by the Centre for Refugee Studies (CRS) at York University in Toronto.

I

$\mathrm{t}$ is a great pleasure for me to be here with you today. In the world of refugees and migration, Canada sets an important example globally in terms of its generosity towards the other, its multicultural, multi-ethnic and multireligious society, its long-standing and rich tradition of asylum as well as its global refugee policies. This tradition is exemplified not least in its annual resettlement programme and Canada's role as a major donor country to UNHCR. The High Commissioner, and UNHCR as an institution, deeply value and appreciate the contributions that the people of Canada, its lively civil society and successive governments have made over time to the protection of refugees and the internally displaced.

In this address I would like to share with you a number of reflections on the changing dynamics of displacement and possible ways forward-the challenging theme of this Conference.
But before doing so, I think it is important to set out briefly the factual background against which this discussion takes place.

At the end of 2010, there were roughly 16 million refugees and asylum-seekers, including 5 million Palestinian refugees. We have detailed population data on 3.5 million stateless around the world but know the overall population is several times larger which is why we continue to map stateless populations. Refugee voluntary repatriation movements in 2010 were the lowest in 20 years. Only 200,000 refugees chose to return home, against an annual average of over a million in the last two decades. The initial estimate for 2011 is slightly better, at some 530,000 returns. Some 26.4 million people were internally displaced, with 3.5 million people newly displaced during 2011 . This is a modest decline in their number, down from 27.5 million in 2010. ${ }^{1}$ Last year also saw the emergence of several new situations of internal displacement. In Côte d'Ivoire, violence following the November 2010 presidential elections forced an estimated half a million people to flee their homes. In Somalia, the worst drought in decades aggravated the country's chronic instability and led to one of the worst humanitarian emergencies of 2011. In Mali, the number of those displaced 
internally has reached almost 150,000 and, according to the Syrian Red Crescent, some 400 to 500 thousand are displaced inside Syria.

In the industrialized world, the year 2011 also witnessed a 20 per cent increase in new asylum applications compared to 2010. However, the increases were not evenly distributed and were evident mainly in the eight Southern European countries, North America as well as Japan and South Korea. For their part, the Nordic countries as well as Australia witnessed a decrease. The USA was the largest single recipient of new asylum applications among industrialized countries, followed by France, Germany, Italy and Sweden. UNHCR conducted refugee status determination in 67 countries, including many countries that are party to the 1951 Refugee Convention, and registered some 80,050 individual applications in 2011. This corresponds to 11 per cent of the global total. It is not surprising that the majority of asylum applications in the industrialized world are lodged by people seeking international protection from war-torn countries or those emerging from conflict, such as Afghanistan, Iraq, Côte d'Ivoire, Libya, Syria and Somalia.

These figures reflect the various developments the world witnessed last year, such as the paradigm shift taking place in North Africa and the Middle East. Yet the figures in the industrialized world need to be juxtaposed with the numbers in some of the main refugee receiving countries in the developing world, notably Kenya, Ethiopia but also Liberia, Niger and other West African countries, plus Mauritania, owing to last year's crises in Somalia, Côte d'Ivoire, and this year's events in Mali, respectively. At the peak of the Somalia crisis last year, for example, several thousand Somalis fled to Kenya and Ethiopia daily. Within a couple of weeks, Mauritania and Niger received some 80,000 refugees from Mali this year, which roughly represents the 20 per cent increase in asylum applications in the industrialized world last year. Tunisia hosted over 100,000 refugees from Libya alone in 2011, despite its own difficulties and political transition. Another interesting phenomenon is the increasing flows to middle income countries, such as Thailand, Malaysia, Turkey, South Africa and Ecuador. ${ }^{2}$ We have also been encouraged by discussions with a range of states, including Australia, Belgium, Brazil and the UK to establish statelessness determination procedures to address the situation of people who otherwise end up in a protection void.

To get a full picture, this statistical overview needs to be seen in the broader context of conflict, migration and related developments which are increasingly intermingled with forced displacement issues. Compared to the estimated 7 billion world population [out of whom some 1 billion go hungry although this is not necessarily linked to movement], the estimated global migration figure for 2010 of approximately 214 million people ${ }^{3}$ is surprising in that one would, I guess, have assumed a much larger portion of the world population would be on the move. Looking at the figure of international migrants from a comparative perspective, it has increased by some 59 million people over the last twenty years, ${ }^{4}$ suggesting higher mobility, primarily for labour reasons. And although violent conflict has declined in the past two decades, one and a half billion people still live in fragile or conflict-affected countries. Another important trend that I would like to flag at the outset is the increase in natural disasters within the last two decades. While in 1990 there were approximately 296 natural disasters recorded, this jumped to 428 in 2010, affecting an estimated 257 million people, ${ }^{5}$ including 42 million displaced in 2010 purely as a result of sudden onset natural disasters. ${ }^{6}$

It is against this backdrop that I would like to explore with you three inter-related themes that I hope can be developed further during this Conference.

\section{Asylum}

The first theme has to do with the atmosphere around refugee protection today, with asylum space and how to enlarge it. Increasingly we hear about "the Thirties" as an apt description of today's ills. I think it was IMF Head Christine Lagarde who evoked it a couple of months ago when talking about the world's financial crisis. While we need to treat historical comparisons with caution for obvious reasons, they nonetheless evoke an atmosphere, real or perceived, which resonates in today's world. This sort of déjà vu has a lot to do with the uncertainties of the economic [and social] crisis, the high unemployment rates in many parts of the world, the stark and growing inequalities within and between societies, and the seemingly intractable challenges of this century which seem unparalleled in complexity and magnitude, such as environmental degradation, the effects of climate change, population growth or the proliferation of weapons of all types. While history does not repeat itself, we can draw lessons from the past to master the present and the future.

The "Thirties" has particular resonance in the refugee and statelessness domain, remembering how the sentiments prevailing in that decade made people stateless and both created refugees and denied them safety in some instances. Inequality, high unemployment and a sense of loss of control are a dangerous mix. They seem to bring out the shadow side of our human nature, in dealings between individuals and in politics. Inward-looking, protectionist and exclusionary tendencies are often the result, not just in the economic realm, leading to the marginalization of groups, the scapegoating of the other [and in particular what appears 
alien to us in the other] and in the case of refugees or stateless people [and migrants more generally] their stigmatization as those who cheat and "abuse" the system, or worse still, are described as criminals. Those on the margins of a society, including refugees, asylum-seekers and the stateless, are easy prey for the gutter press and populist politicians who are eager to play with fire. This phenomenon has already emerged in some countries where the public debate on asylum and migration policies has become so toxic as to preclude any reasonable or clear-headed dialogue. Could this be possible without the indifference of the majorities to the concerns and situation of the minorities?

As Tony Judt remarked before his untimely death in August 2010, "what we know of World War II-or the former Yugoslavia-illustrates the ease with which any society can descend into Hobbesian nightmares of unrestrained atrocity and violence. If we are going to build a better future, it must begin with a deeper appreciation of the ease with which even solidly-grounded liberal democracies can founder." concludes by saying that "much of what is amiss in our world can best be captured in the language of classical political thought: we are intuitively familiar with issues of injustice, unfairness, inequality and immorality-we have just forgotten how to talk about them."

We should not be drawn into a fatalistic mindset by the comparison with the past [implied in the "Thirties"]. The fact that parallels are being drawn with that critical point in time does not, of course, mean that there is any terrible or inevitable catastrophe ahead of us today. The course that global events will take in the coming decades will, to an overwhelming extent, be determined by the actions and directions that states-most of which are led by elected politicians-will take. This means that we, as citizens, have choices, and responsibilities, that will play a key role in the shaping of the future.

It is therefore all the more important to recognize that attitudes toward international refugee protection serve as a kind of litmus test of the health of our democratic societies. The institution of asylum is itself a reflection of values such as justice, fairness and equality-its existence an indicator of the importance of these values in society as a whole. Offering sanctuary to those at risk is not just an ancient tradition but a legal and indeed a moral necessity. It is the safety valve for those who aspire to a better world through their political action, for those who are discriminated against because of their religious beliefs, their gender, or who are stigmatized simply as a result of who they are. It was as important when Hungarians or Czechs or Poles fled repressive regimes after the Second World War as it is now when people-for instance, in North Africa and parts of the Middle East-have no choice but to leave their countries because of violence, autocratic rulers or severe discrimination. The importance of asylum cannot be separated from any democratization process, on the contrary it has often been a conduit for democracy.

How is the time-honoured institution of asylum faring today?

The answer is mixed. In 2011 we witnessed the amazing generosity both of people and of countries. Just to give you a few examples, Tunisian families opened their homes to accommodate thousands of Libyan refugees. Similarly people in Liberia welcomed Ivorian refugees, and Jordanians opened their doors to those fleeing Iraq and Syria. A number of countries passed decrees or are working on laws to put these practices on a more solid legal footing. Grass roots organizations in several countries advocated strongly for an open door policy towards refugees and for resettlement of specific groups, to demonstrate international solidarity and burden-sharing. And more generally, in the West, the granting of asylum has paved the way for the integration for tens of thousands of people every year, thus engendering an immediate solution - an aspect that is often overlooked and not sufficiently appreciated.

At the same time, we have also seen signs of what is colloquially referred to as "asylum fatigue" both in the North and the Global South. It is numbers that appear to count. The success of today's asylum policies seems to hinge more on keeping numbers down and people out [or ensuring the perception that these elements are "under control"], rather than ensuring access to safety, the management of the asylum systems in a spirit of solidarity, or crafting solutionoriented arrangements. Regrettably there is a lot of negative discourse in political and public debates around asylum, where legitimate concerns about misuse, smuggling and trafficking trump concerns about saving lives and doing the right thing. Efforts to adapt the institution of asylum to respond to these real challenges should not threaten the effective operation of the entire institution itself. Suffice to note the excessive media reporting on the fate of a luxury cruise ship run aground in Italy earlier this year or on the $100^{\text {th }}$ anniversary of the sinking of the Titanic and compare this to the lacklustre reporting on last year's rescue-at-sea crisis in the Mediterranean, when more than 1,500 refugees and stranded migrants lost their lives attempting to flee Libya by boat. In a particularly sobering report on loss of life in the Mediterranean, the Council of Europe documented the collective failure to come to the rescue of those fleeing Libya by boat. ${ }^{9}$ I wonder whether what played out in the Mediterranean last year is not symptomatic of a broader crisis of lack of solidarity and indifference affecting the very core of the institution of asylum today.

What can we do about it? There is no easy answer. 
I am convinced that it is important to go back to basics, both in legal and moral terms. Asylum requires the right to flee, granting access to territory, determining claims fairly and expeditiously, as well as ensuring fair treatment plus paving the way for the resumption of normal lives. It requires that refugees should not be forced to turn to smug glers, that they should not be mandatorily detained or be separated from their families, that border control and interception measures are mindful of the needs of refugees and other groups with specific needs, protection and otherwise, and that legal intricacies are resolved with due regard for the fundamental purpose of the legal regime established in their favour. More broadly, but also more basically, it requires treating people with humanity and fairness.

By way of example, appropriate measures are indeed necessary to combat people smuggling and trafficking in human beings. But combating such crimes needs to go hand-in-hand with proper protection safeguards of the sort envisaged by the Palermo Protocols ${ }^{10}$ - safeguards to ensure that the victims of such crimes, not least those who are asylum-seekers and refugees, are not penalized and can gain access to protection, in the many cases where it is needed. Mandatory detention regimes for certain categories of asylum-seekers have not only wrought suffering and long-term psychological harm for the detained, but have also provoked a considerable public backlash. UNHCR has regularly pointed to the problems associated with differentiated treatment of various groups of asylum-seekers and refugees, depending on the mode of arrival, to the quality of decision-making, as well as to the need for effective remedies being made available through an appeal process which offers substantive review both of the facts and the law. The difference in mode of arrival does not necessarily justify distinct statuses being accorded to refugees.

A lot more work also needs to be done to explore the potential refugees offer to spur development, both in the developing world but also in the rapidly aging developed world. With so many protracted refugee situations with no end in sight and consistently low numbers of voluntary returns to countries of origin, this requires a new hard look at solutions that combine local opportunities with a development perspective and, in addition, look to broader immigration regimes from which refugees might also benefit. An interesting suggestion was, for instance, made how Dadaab refugee camp in Kenya could become a force for development. ${ }^{11}$ In line with this thinking, UNHCR has been working with UNDP on a Transitional Solutions Initiative which aims to transform the humanitarian response to protracted displacement situations, such as in Sudan, Colombia and Nepal, into a development intervention benefiting entire communities.
Another sign of hope was last year's Ministerial Meeting on the occasion of the anniversaries of the refugee and statelessness conventions, which sent an important signal that there are fundamental human values which must not be compromised. The fact that over 100 states solemnly deposited concrete pledges to address refugee protection and statelessness issues will not only improve the fate of thousands of people but is in and of itself a clear message. It was equally important that last week the Organization of Islamic Cooperation held the Ashgabat Conference on Refugees in the Muslim World, pointing out the inter-linkage between Islamic concepts of asylum and their modern legal manifestations. This coming December the annual High Commissioner's Dialogue on Protection will take the form of an inter-faith dialogue on protection, remembering the common heritage of traditions of compassion and welcoming, but also building new alliances that can help address concrete protection issues for displaced and stateless persons.

We need political and moral leadership, combined with individual engagement, to overcome the tendency to exclude and look inwards. Strong voices are needed to explain why it is in everyone's interest to protect the disenfranchised and promote their potential contribution to the economic and social fabric of our societies.

\section{Interdependence}

The second theme I'd like to explore is the increasing interdependence and inter-linkage of the causes of human mobility, especially in light of the challenges that I have just mentioned. Obviously, our interest at UNHCR is in those movements that do not occur as a result of a free choice but due to circumstances that are involuntary. Our interest lies in the shared protection concerns that such movements necessitate, whether or not they are covered by existing normative and governance frameworks.

Increasingly, we see, for instance, how food insecurity or water scarcity [sometimes avoidable through effective governance], marginalization of vulnerable groups and violence become interlinked, as well as how inequality exacerbates poverty and could accelerate the spiral of violence. Different UN and development reports are replete with analyses about massive disparities between and within regions and countries, about the unequal sharing of the benefits of globalization, including from a gender equality perspective, and about our current volatile economic model, which has neglected social justice and the impact on the environment. ${ }^{12}$ By way of examples, the Asia Development Bank, in a recent report, has warned that Asia's rapid economic growth may undermine stability because the gap between the rich and the poor is 
widening. ${ }^{13}$ The same can be said with respect to Africa, where governments' ambitious commercialization of agriculture and "land grabs" are destroying traditional livelihoods and pushing people off their lands. ${ }^{14}$ Food insecurity combines with and magnifies violence as causes for flight, as we witnessed last year in Somalia. Another recent example is the situation in the Sahel which has been harsh for many years, with millions of people suffering from chronic drought, food insecurity, malnutrition and, more recently, from violent conflict. Since the beginning of the year, this has led to the internal displacement of just under 150,000 people in Mali and an estimated 160,000 refugees in Mauritania, Niger, Burkina Faso, Togo and Guinea Conakry. The displaced are settling in areas parched by drought, where local communities are already struggling to cope with its consequences. The situation in many ways exemplifies the entire spectrum of today's complex mix of challenges ranging from changes in the external environment, weak governance structures, conflict and displacement. The question arises as to what sort of protection needs to be offered to persons who are forced to move because of these "other" causes.

Important causes for forced movements remain indiscriminate violence and complex conflicts involving multiple agents of violence. Civilians will remain the most affected and it will be progressively difficult for humanitarian agencies to operate. Although the number of conflicts has decreased in the past ten years, not many situations have actually been resolved, as illustrated by the many protracted refugee situations around the world. In the meantime there is a transformation in the way violence is occurring, with a strong correlation between state fragility and violence. In many parts of the world, "private actors" of violence are gaining ground, many of whom are involved in organized crime but do not generally fall within the commonly understood category of non-state actors or de facto authorities: gangs, vigilante groups, drug cartels or organisations with radical aims. By way of example, in Iraq armed groups seem to engage increasingly in organized crimes such as extortions, kidnappings for ransom and robberies to fund their activities, resulting in a deadly combination of persecution and common crime. ${ }^{15}$ When a state is weak, there is an increase in non-state actors with maleficent objectives, such as in Somalia or in northern Mali. However, state fragility is not only prevalent in Somali-type situations, but also in different parts of otherwise well-functioning states, including middle-income countries. The stereotypical categorisation of "fragile" low-income and "robust" middle-income countries to map violence-induced humanitarian crises is no longer holding true. Sometimes these actors of violence are closely affiliated with national or local authorities, with a marked adverse impact on humanitarian space. UNHCR has embarked on a major research project that, we hope, will help us to develop international protection guidelines concerning persons displaced by indiscriminate violence, conflict and the changing actors of violence. ${ }^{16}$

Another global issue and multiplier of other causes of forced displacement is climate change. Darfur is often noted as an example of how environmental degradation and competition over scarce resources over decades can combine to trigger conflict-induced displacement. Another case in point is the situation in the Horn of Africa, where environmental stress has always been embedded in the region's cycle of conflicts. We have just contributed to a study that examined the interface between climate change, vulnerability and refugee outflows. ${ }^{17}$ Some of the more interesting findings indicate, for instance, that many of the refugees interviewed had perceived discernible shifts in the climate in their home countries over the past ten to fifteen years. While they did not refer to the impacts of climate change as a direct catalyst for violent conflict, the scarcity of resources exacerbated by worsening weather conditions was often cited as a multiplier or magnifier of pre-existing conflicts. They also mentioned that violent conflicts and state repression reduced the adaptation capacity of those exposed to climate change. Again, this reveals that there is perhaps a stronger link between "traditional" refugee law premised on a notion of persecution and modern displacement phenomena, such as the consequences of climate change, than hitherto understood. This is certainly the case where the impact of climate change-related processes act as causes of, or exacerbate, conflict, violence, state repression or public disorder. Deleterious action or inaction by a government to address disaster risk reduction or preparedness or, once disaster strikes, to deal with its humanitarian consequences, if related to one or more of the Convention grounds, may well be considered persecution within the meaning of the 1951 Refugee Convention. This said, it is equally clear that there is a normative gap affecting people who may be forced to cross an international border owing to the impact of rapid-onset meteorological events, possibly linked to climate change. ${ }^{18}$ It is very encouraging that Norway and Switzerland, joined by Mexico and Germany, deposited a pledge at the Ministerial Meeting last year "to cooperate with interested states, UNHCR and other relevant actors with the aim of obtaining a better understanding of such cross border movements at relevant regional and sub-regional levels, identifying best practices and developing consensus on how best to assist and protect the affected people."

Thus if we look at today's crises and those that in future may generate population movements, they range from various forms of violence, human rights violations, acute and 
slow onset natural disasters to political instability, epidemics/pandemics, nuclear and industrial accidents, and others. Increasingly, they are intertwined and mutually reinforcing. Some have suggested new terminology, such as the concept of "crisis migration". ${ }^{19}$ This is thought-provoking but at the same time I wonder whether such a concept does justice to particularly acute humanitarian situations, the forced displacement angle, the underlying legal and protection framework for people who are forcibly displaced or the indivisibility of human rights.

A stark example of the magnitude of today's displacement challenges is evident in the scenarios that developed as a result of the conflict in Libya last year. Tunisia and Egypt bore the brunt of these displacement challenges, hav ing to cope with over a million people departing Libya. The vast majority of them were migrant workers forced to leave Libya because of the conflict but who could be assisted to return home. But there were also well over 100,000 Libyans who sought safety in both neighbouring countries, as well as some 6,000 refugees, primarily from Eritrea and Somalia, who were stranded at the borders in Tunisia and Egypt. In response, and developing an innovative operational model, IOM and UNHCR launched a massive humanitarian evacuation programme for third country nationals who wanted help to get back to their respective countries of origin in Asia and Sub-Saharan Africa. At the same time, in an effort to demonstrate solidarity with Tunisia and Egypt within a context of international cooperation, UNHCR set in train a Global Resettlement Initiative for refugees stranded at the border, as well as a programme supporting host families. In this crisis, migrant workers were the single largest category of people who were displaced. This is raising interesting questions regarding a gap in the international legal systemhow to protect migrants who are "trapped" or "displaced" by armed conflict and other emergencies? ${ }^{20}$

Importantly, these various examples point to the key role of the state. It is clear that the state has crucial responsibilities both in terms of preventing or mitigating causes of displacement and when responding to them. There was a time when commentators predicted the gradual replacement of certain state functions by supranational bodies, be they intergovernmental, commercial or private, or by multinational companies. In the wake of the economic and financial crisis, however, the central role of the state has again come to the fore-with full force. We need to ask ourselves what this means in the context of forced displacement, humanitarian action and protection. Statehood is inextricably linked to providing a safe and secure environment, guaranteeing the functioning of effective institutions and basic services, including the safeguarding of human rights and the rule of law, and a capable administration. If a state cannot deliver or can only partially deliver its core functions -- for instance, by not being able to control all its territory, or because of weak or fragile state structures, and as a result is either unable or unwilling to exercise effectively its core raison d'être in part or the whole of its territory -- a need for international protection may arise.

International assistance and protection are often undermined by lack of humanitarian access and presence. In these scenarios, the resilience of communities and individuals and their ability to protect themselves are critical. UNHCR relies on grass-roots networks and implementing partners to deliver services in many areas, including in countries such as Somalia. At the height of the displacement of Somalis into Kenya in 2011 and the associated security crisis within some of the refugee camps in Kenya, refugees themselves played a significant role in ensuring the continuation of delivery of key services in the emergency situation.

It is also interesting to observe that the Security Council consistently makes pronouncements on the need for humanitarian access and the delivery of humanitarian assistance. The denial to access and delivery by authorities or non-state actors and the consequences for affected populations therefore become an international concern. This may well become a major issue in the future, including from a forced displacement and protection perspective, especially when we may increasingly see government inaction, lack of preparedness, etc. in response to environmental hazards, natural disasters, food and water insecurity and so forth. We may increasingly witness the interconnectivity between government action or the lack thereof [including due to deliberate discrimination], changing weather patterns and their consequences, ${ }^{21}$ governance structures on food and water security that do not respond to addressing inequality, as well as operational humanitarian responses to what may well be major sources of displacement in the future.

Again, this points to the interconnectedness of phenomena, of causes of human mobility, of migration and displacement, the way the state addresses them and the legal and protection underpinnings. The interesting feature is that it will, I think, engage UNHCR and the institution of asylum from a traditional mandate perspective. It would be interesting to undertake further research in this regard, including from the perspective of persecution and refugee law. But it is clear that both normative and operational protection gaps exist, which leads me to my last theme: governance.

\section{Governance}

Against this backdrop, it is obvious that good governance at all levels will be the linchpin for mastering these challenges. A lot of thought was given to global governance at 
the beginning of the 1990s, not least in the wake of the end of the Cold War and the hope for a new quality of multilateral engagement. But not long after the publication of the report by the Commission on Global Governance in 1995, ${ }^{22}$ it seems the world has again been struggling to organize itself at different levels to come to terms with the challenges of our inter-connected world today. It is true that progress has been made, for example, with the adoption of the Millennium Declaration and Goals, ${ }^{23}$ development of the "responsibility to protect" concept ${ }^{24}$ to respond to the most heinous crimes, such as genocide and other crimes against humanity, as well as a major reform of the human rights architecture, just to mention a few. Yet the 2005 UN report "In Larger Freedom" is clear about the urgency of proper governance: ${ }^{25}$

In a world of inter-connected threats and opportunities, it is in each country's self-interest that all of them are addressed effectively. Hence, the cause of larger freedom can only be advanced by broad, deep and sustained global cooperation among States... . The world needs strong and capable States, effective partnerships with civil society and the private sector, and agile and effective regional and global intergovernmental institutions to mobilize and coordinate collective action. The United Nations must be reshaped in ways not previously imagined, and with a boldness and speed not previously shown... . it is for us to decide whether this moment of uncertainty presages wider conflict, deepening inequality and the erosion of the rule of law, or is used to renew institutions for peace, prosperity and human rights. Now is the time to act.

With the slow progress on climate change, especially on the urgently needed legally binding agreement to curb carbon gas emissions, and other major global issues, this appeal is even more relevant today than it was seven years ago. Reflecting on multilateralism in today's world, I have discerned at times a push-back against international institutions, a re-emergence of old reflexes with an over-emphasis on national sovereignty and statehood, a questioning of the role of regional human rights mechanisms, notably the European Court of Human Rights as well as the institutions of the Inter-American human rights system, and key principles of human rights, including, in some quarters, the prohibition on torture. Humanitarian work has become more complicated as a result, with access to affected populations recurrently blocked, and established standards, such as the Guiding Principles on Internal Displacement, being challenged on occasion.

Even in the consensus world of humanitarian action and refugee affairs we have seen of late a difficult debate about the value of Executive Committee Conclusions-important standard-setting texts on protection issues adopted annually by UNHCR's governing body comprising 87 states. The Executive Committee did not adopt a Conclusion last year and no agreement has so far been reached whether one will be adopted this year nor, critically, on the way forward.

In fact, what we need today, more than ever before, is a deep reflection about how the world could be structured in terms of rules, governance and institutions to deal with the major global issues in an effective manner. As Brian Urquhart wrote: "What is needed now is not to abolish national sovereignty but to reconcile it with the demands of human survival and decency in the astonishingly dangerous world we have absentmindedly created." 26 In doing so, it is important to bear in mind the achievements to date.

One bright spot in this challenging international environment is, for example, the increasing role of international human rights mechanisms. Despite some difficult starts, the Human Rights Council is advancing with its new mechanisms, such as the Universal Periodic Review, becoming an important tool for reaching consensual and collaborative solutions. During the first UPR cycle, more than 1,600 recommendations concerning the human rights treatment of persons of concern to UNHCR were made to states under review. The Council has increasingly relied on inquiry and fact-finding missions. Its special sessions were used to examine major events and developments such as the human rights impact of natural disasters, the 2010 earthquake in Haiti, the financial crisis or the food price hikes in 2008. Its special procedures have become authoritative sources of monitoring and standard-setting. These positive aspects, however, do not hide the fact that the Council also remains a body where political differences influence outcomes.

Let us also not forget that it is in response to transnational challenges that UNHCR was established as one of the main global humanitarian and protection institutions in the wake of the Second World War. Its creation emerged from the experience of different international refugee institutions that had been established in the inter-war period but, more importantly, recognized the urgency of the international character of protection and humanitarian engagement, not least in the wake of the Second World War. Additionally, UNHCR's mandate for refugees and stateless people has been grounded in public international law, and in particular international treaty law. UNHCR is legally entitled to intercede directly on behalf of refugees and stateless persons who would otherwise not be represented on the international plane. If you think this through historically, this is an amazing advancement over the "interference in domestic affairs" doctrines of the past. The effective exercise of this mandate is underpinned by the commitment of states to cooperate with the Office. ${ }^{27}$ Some of UNHCR's 
functions are also embedded in international law concepts more broadly, such as the surrogate function of diplomatic and consular protection for refugees or international human rights protection concepts.

In this context, it is also important to bear in mind that UNHCR's involvement in internal displacement and mixed-migration contexts entails close partnership with other actors. The year 2012 marks the $20^{\text {th }}$ anniversary of the mandate of the Special Rapporteur on the Human Rights of Internally Displaced Persons. A lot has changed since then. The Guiding Principles were elaborated. The cluster system to respond to humanitarian crises, including internal displacement, has been established. More recently, major regional normative developments include adoption of the Great Lakes Protocol and the Kampala Convention. UNHCR has actively participated in and supported these developments. The same holds true with respect to UNHCR's increasing engagement with others in addressing the international protection needs of those who find themselves in mixed-migration and trafficking contexts, as well as of the stateless.

In short, the international community has created a vehicle that translates its international concern in the forced displacement and statelessness domain into a legal, institutional and operational framework. On a daily basis, this constitutes the nuts and bolts of humanitarian action and protection delivery at the grass-roots level. At times this has meant progressive development of international law and standards. This work always requires international cooperation and partnership both at the intergovernmental, governmental and non-governmental level. This institutional setting is an important achievement of the last century, one that transcends narrow thinking and inwardness. It constitutes the platform on which to build when we look to dealing with the new challenges.

On the international rule of law front, it is encouraging that various initiatives addressing causes of displacement have been addressed through international regulatory and governance frameworks. For example, in relation to the buying of so-called "blood diamonds" the Kimberley Process Certification Scheme ${ }^{28}$ was put in place. As for the selling of small arms, we have high expectations for the July UN Diplomatic Conference on the Arms Trade Treaty, where we hope Member States will strive for a comprehensive coverage of an otherwise poorly regulated global trade in conventional weapons. ${ }^{29}$ As these examples show, it is clear that new standards will continue to be needed in the future, including in the areas more directly of concern to UNHCR.

It is important for an agency such as ours to reflect constantly about the adequacy of today's tools and instruments, not least in light of the aforementioned challenges.
Concepts of state responsibility and international protection, as we are familiar with them today, will need to evolve to take into account not only the global repercussions of human activities but also their inter-generational impact. Standard-setting may well take new shapes and forms in the future, requiring some serious creative thinking. I'd like to give you five examples where a discussion needs to be had on the progressive development of international law and standards.

One area that would benefit from further reflection are protection responses to both sudden- and slow-onset disasters, including if they lead to displacement across borders and are not covered by existing instruments. Last year's Nansen Conference on Climate Change and Displacement in Oslo developed some parameters that both the Norwegian and Swiss Governments have undertaken to take further through the Nansen Initiative, which has been launched this year. A second area where more work is required is in relation to protection of migrants and refugees at sea, to avoid the type of situations to which I referred earlier. A third area applies to regions, such as the Middle East and parts of Asia, where many states are not party to the 1951 Refugee Convention. In such contexts one could think of the development of regional protection regimes that identify the circumstances under which temporary protection would be activated, set out its scope, content and duration, while clarifying procedural and standard of treatment issues. A fourth area would be statelessness where we have recently seen a new dynamic around accessions to the two international statelessness instruments. Moreover, would there not be benefit to codify existing ILC standards in respect of state succession and nationality? And finally, a proper application of the 1951 Refugee Convention needs to be reinvigorated to address the protection needs of people fleeing armed conflict and other situations of violence. I hope this gives some food for thought for important global governance issues in the forced displacement and statelessness domain.

\section{Conclusion}

As we see increasingly, if the effects of some of these global issues are not yet being felt because they develop gradually and if there is no immediate crisis, then existing governance systems seem to delay their resolution. It is the same in the case of inter-generational equity and justice. But we can't afford this. The increasingly complex displacement angle is both a visible manifestation of many of today's global challenges, as well as a trans-boundary issue in its own right. It should ring alarm bells more widely and trigger the action required to address the core issues and to craft effective governance around them. It will, I think, not surprise you-in 
light of all I have just said - that the next edition of the State of the World's Refugees will have as its theme: "In Search of Solidarity". It is the human value that is both the ingredient for holding societies together in difficult times and for ensuring that basic human rights are respected. It is the human value that has inspired international cooperation and international law and projected a vision of our common heritage. It is also the value that will, if acted upon, guarantee our survival. In this spirit, I look forward to your contributions from this Conference.

\section{NOTES}

1. See that latest IDMC report, The Global Overview 2011, People Displaced by Conflict and Violence, available at http://www.unhcr.org/IDMC/IDMC-report.pdf

2. See Nicholas Van Hear, "Shifting powers: two decades of migration and global turbulence," The Compass Blog, October 11, 2011, available at http://compasoxfordblog .co.uk/2011/10/shifting-powers-two-decades-of-migration -and-global-turbulence/. See also Nicholas Van Hear, "Forcing the Issue: Migration Crises and the Uneasy Dialogue between Refugee Research and Policy," Journal of Refugee Studies 25, no. 1 (2012):2-24.

3. See http://www.iom.int/jahia/Jahia/about-migration/facts -and-figures/lang/en

4. See United Nations, Department of Economic and Social Affairs, Population Division, Trends in International Migrant Stock: The 2008 Revision (United Nations database, POP/DB/MIG/Stock/Rev.2008), 2009, available at http:// esa.un.org/migration/p2k0data.asp

5. EM-DAT: The OFDA/CRED International Disaster Database available at www.emdat.be

6. IDMC, Displacement due to natural hazard-induced disasters: Global estimates for 2009-2010, June 2011, p4.

7. See Tony Judt, Ill Fares the Land, 2010, p. 221.

8. Ibid. p. 234.

9. The report is available at: http://assembly.coe.int/ CommitteeDocs/2012/20120329_mig_RPT.EN.pdf.

10. Protocol to Prevent, Suppress and Punish Trafficking in Persons, Especially Women and Children, supplementing the United Nations Convention against Transnational Organized Crime, U.N. Doc. A/53/383 (2000), available at http:// www.uncjin.org/Documents/Conventions/dcatoc/final_ documents_2/convention_\%20traff_eng.pdf; The Protocol against the Smuggling of Migrants by Land, Sea and Air, supplementing the Convention against Transnational Organised Crime, U.N. Doc, A/55/25 (2000), available at http://www2. ohchr.org/english/law/organizedcrime.htm

11. See, Melanie Teff, Kenya can turn the Dadaab refugee camps into an asset at http://www.guardian.co.uk/ global-development/poverty-matters/2012/apr/18/ kenya-turn-dadaab-into-asset
12. See CEB Joint Statement to Rio+20 at http://www. uncsd2012.org/rio20/content/documents/528CEB-2012-1 -RioStatement-17April2012.pdf

13. See press release http://www.adb.org/news/asias-increasing -rich-poor-divide-undermining-growth-stability-adb -report

14. See Human Rights Watch, 2012, Waiting for Death: Forced Displacement and the "Villagization" in Ethiopia's Gambella Region, http://www.hrw.org/reports/2012/01/16/ waiting-here-death

15. See UNHCR Eligibility Guidelines for Assessing the International Protection Needs of Iraqi Asylum-Seekers, available at http://www.unhcr.org/refworld/docid/49f569cf2.html

16. See, for example, the UNHCR-commissioned study by Theo Farrell and Olivier Schmitt, The Causes, Character and Conduct of Armed Conflict, and the Effects on Civilian Populations, 1990-2010, PPLA/2012/03, available at http:// www.unhcr.org/refworld/docid/4f8c3fcc2.html; UN High Commissioner for Refugees, Safe at Last? Law and Practice in Selected EU Member States with Respect to Asylum-Seekers Fleeing Indiscriminate Violence, 27 July 2011, available at: http://www.unhcr.org/refworld/docid/4e2ee0022.html

17. See Koko Warner, Tamer Afifi, Patrick Sakdapolrak, Radha Govil, Climate Change, vulnerability and human mobility: perspectives of refugees from the East and Horn of Africa, (forthcoming).

18. See Summary of Deliberations, Expert Meeting on Climate Change and Displacement 22-25 February 2011, Bellagio, Italy, available at http://www.unhcr.org/4da2b5e19. html; Chairperson's Summary, Nansen Conference on Climate Change and Displacement in the 21st Century, Oslo, 6-7 June 2011, available at http://www.unhcr.fi/fileadmin/user_upload/PDFdocuments/2011_News/NansenConf_ClimateChange.pdf; The Nansen Principles on Climate Change and Displacement, available at http://www .regjeringen.no/upload/UD/Vedlegg/Hum/nansen_ prinsipper.pdf; Statement by António Guterres, United Nations High Commissioner for Refugees, Nansen Conference on Climate Change and Displacement, Oslo, Norway, 6 June 2011 available at http://www.unhcr.org/4def7ffb9. html; Remarks by Volker Türk, Director of International Protection, UNHCR, Can protection of environmentally displaced persons be found in existing protection regimes? What are the next steps from a protection perspective? Nansen Conference on Climate Change and Displacement, Oslo, Norway, 6 June 2011, available at http://www.unhcr. org/4def8e3c9.html

19. IOM, Moving to Safety: Migration Consequences of Complex Crises-Chair's Summary, available at: http://www. iom.int/jahia/webdav/shared/shared/mainsite/microsites/ IDM/workshops/moving-to-safety-complex-crises-2012/ Chairs-Summary-EN.pdf. See also http://www.iom. int/jahia/Jahia/policy-research/international-dialogue -migration/intersessional-workshops/moving-to-safety -migration-consequences-of-complex-crises-2012/lang/en 
20. Khalid Koser, Migration, Displacement and the Arab Spring: Lessons to Learn, Brookings Institution, 2012, http:// www.brookings.edu/opinions/2012/0322_arab_spring_ migration_koser.aspx

21. See Field, C.B., V. Barros, T.F. Stocker, D. Qin, D.J. Dokken, K.L. Ebi, M.D. Mastrandrea, K.J. Mach, G.-K. Plattner, S.K. Allen, M. Tignor, and p.m. Midgley (eds.), Managing the Risks of Extreme Events and Disasters to Advance Climate Change Adaptation, Special Report of the Intergovernmental Panel on Climate Change (IPCC), A Special Report of Working Groups I and II of the Intergovernmental Panel on Climate Change, Cambridge University Press, Cambridge, UK, and New York, NY, USA. Available at http://www.ipcc -wg2.gov/SREX/images/uploads/SREX-All_FINAL.pdf

22. See Commission on Global Governance, Our Global Neighbourhood, 1995.

23. General Assembly resolution A/RES/55/2. See http://www. un.org/millennium/declaration/ares552e.htm

24. A particular tribute goes to Canada in this regard and former Foreign Minister Lloyd Axworthy. The "responsibility to protect" concept was first introduced in November 2001 by the Canadian-sponsored International Commission on Intervention and State Sovereignty.
25. SeeExecutiveSummaryathttp://www.un.org/largerfreedom /executivesummary.pdf and UN doc. A/59/2005 of 21 March 2005, paras 18, 221.

26. See Brian Urquhart, Finding the Hidden UN, The New York Review of Books, 27 May 2010, at http://al.odu.edu/mun/ docs/Article_NYbookreview_27_May_2010.pdf

27. The obligation of states to cooperate with UNHCR is, for instance, explicitly mentioned in international and regional legal instruments for the protection of refugees, notably the 1951 Convention and 1967 Protocol relating to the Status of Refugees: directly, for example, in Articles 35 and 36 of the 1951 Convention, and indirectly, for example, in Article 11 of the 1961 Convention on the Reduction of Statelessness following designation by the General Assembly.

28. See General Assembly resolution A/RES/55/56 and Security Council resolution 1459.

29. See in particular the joint statement of UN agency chiefs for a comprehensive and robust arms trade treaty, at http:// www.unhcr.org/4f3e50d96.html

Volker Türk is Director of International Protection at the UNHCR. 